\title{
Primula calyptrata, a New Species in Section Carolinella (Primulaceae) from Yunnan, China
}

\author{
Gong Xun and Fang Rhui-cheng \\ Kunming Institute of Botany, Chinese Academy of Sciences, Kunming 650204, China. \\ gongxun@mail.kib.ac.cn
}

Abstract. Primula calyptrata X. Gong \& R. C. Fang (Primulaceae) is described and illustrated. Analysis of its habitat, distribution, and capsule morphology indicates that this species is a member of Primula sect. Carolinella (Helmsley) Pax, which is endemic to humid subtropical regions of Yunnan, China, northern Vietnam, and Thailand, and characterized by an unusual calyptrate capsule.

Key words: China, Primula, Primulaceae, section Carolinella, Yunnan.

During an investigation of plants in southeastern Yunnan, China, in April 2001, some specimens of Primula were collected and recognized as a new species. After further studies, the species was believed to belong to section Carolinella. Living plants were introduced into Kunming Botanical Garden for cultivation and observation. Specimens were also collected by Shui Yu-min et al. from Zhongzai in Malipo County, Yunnan Province, in 2002.

Members of section Carolinella are unique in Primula for having a calyptrate capsule with a circumscissile lid, a feature also shared by the genera Pomatosace Maximowicz, Anagallis L., Soldanella L., and Bryocarpum Hooker f. \& Thomson in Primulaceae (Pax \& Knuth, 1905). The evolutionary trend of the fruits in Primulaceae is believed to be from indehiscent capsule to valvate capsule to calyptrate capsule with a circumscissile lid (Hu QM., 1994; Chen F-H. \& Hu, 1990). This feature in section Carolinella is a link between Primula and the other genera; however, other morphological characters and distribution clearly separate them. The phylogenetic relationships among other sections in Primula and other genera of Primulaceae are still unclear because studies are lacking in chromosome number, pollen type, and seed morphology. The phenomenon that the calyptrate capsule occurs in the genera Pomatosace, Anagallis, Soldanella, and Bryocarpum in Primulaceae may be a result of convergent evolution (Kong \& Liu, 1999).

Section Carolinella is believed to be a primitive group in Primula (Hu Q-M., 1994); this new taxon is considered to be primitive for having alternate and long-petioled leaves, $2-2.5 \mathrm{~cm}$ long stems, and homostylic flowers. In addition, Primula sect. Carolinella is a typical endemic of East Asia and is limited to southwestern and southern China and adjacent North Vietnam and Thailand. Eleven species were recognized in this section: almost all are stenochoric and have very small populations, some of which are in imminent danger. All of the species in this section occur in the warm-moist southern subtropical evergreen broadleaf forest of low altitudes within the limestone region.

Primula calyptrata X. Gong \& R. C. Fang, sp. nov. TYPE: China. SE Yunnan: Malipo County, Xiajinchang, 1870 m, 16 Apr. 2001, X. Gong 02815 (holotype, KUN). Figure 1.

Species in hac sectione caulibus brevibus, foliis subtus purpuratis valde differt. Planta $P$. intanoensi e Thailandia valde proxima, sed caulibus $2-2.5 \mathrm{~cm}$ longis, foliis alternantibus, corollis purpureis, tubis $1.7 \mathrm{~cm}$ longis, limbis $1.5-1.8 \mathrm{~cm}$ in diam., pedicellis $2-4 \mathrm{~mm}$ longis differt.

Herbs perennial, completely efarinose, stems and both surfaces of leaf blade as well as petioles with dense articulated hairs. Rhizome elongated, 2 $\mathrm{cm}$ long, with numerous fibrous roots, producing 1 or 2 leaf-bearing stems above. Stem $2-2.5 \mathrm{~cm}$ long before or in anthesis, purple. Leaves alternate, leaf blade suborbicular, 2.8-4 $\times 2.6-3.8 \mathrm{~cm}$, apex rounded, base cordate, margin irregularly undulate, thick-papyraceous when dry, grayish green above, purple below, midrib and 4 pairs of lateral veins obscure above and plane but distinct below; petiole $2.5-5.5 \mathrm{~cm}$ long. Scape 1 or $2,12-18 \mathrm{~cm}$ high, sparsely white villous, with 1 to 2 superimposed umbels with 2 to 5 slightly secund flowers in each; pedicels 2-4 mm long, with dense articulated hairs; bracts ovate-lanceolate, 4-6 mm long, prominently 1-nerved, with dense articulated hairs; calyx campanulate, 5-6 mm long, with dense articulated hairs, divided to $1 / 2-1 / 3$ into ovate-triangular lobes, lobe with 3 distinct nerves; corolla purple with a yellow eye, salverform, pubescent outside, 


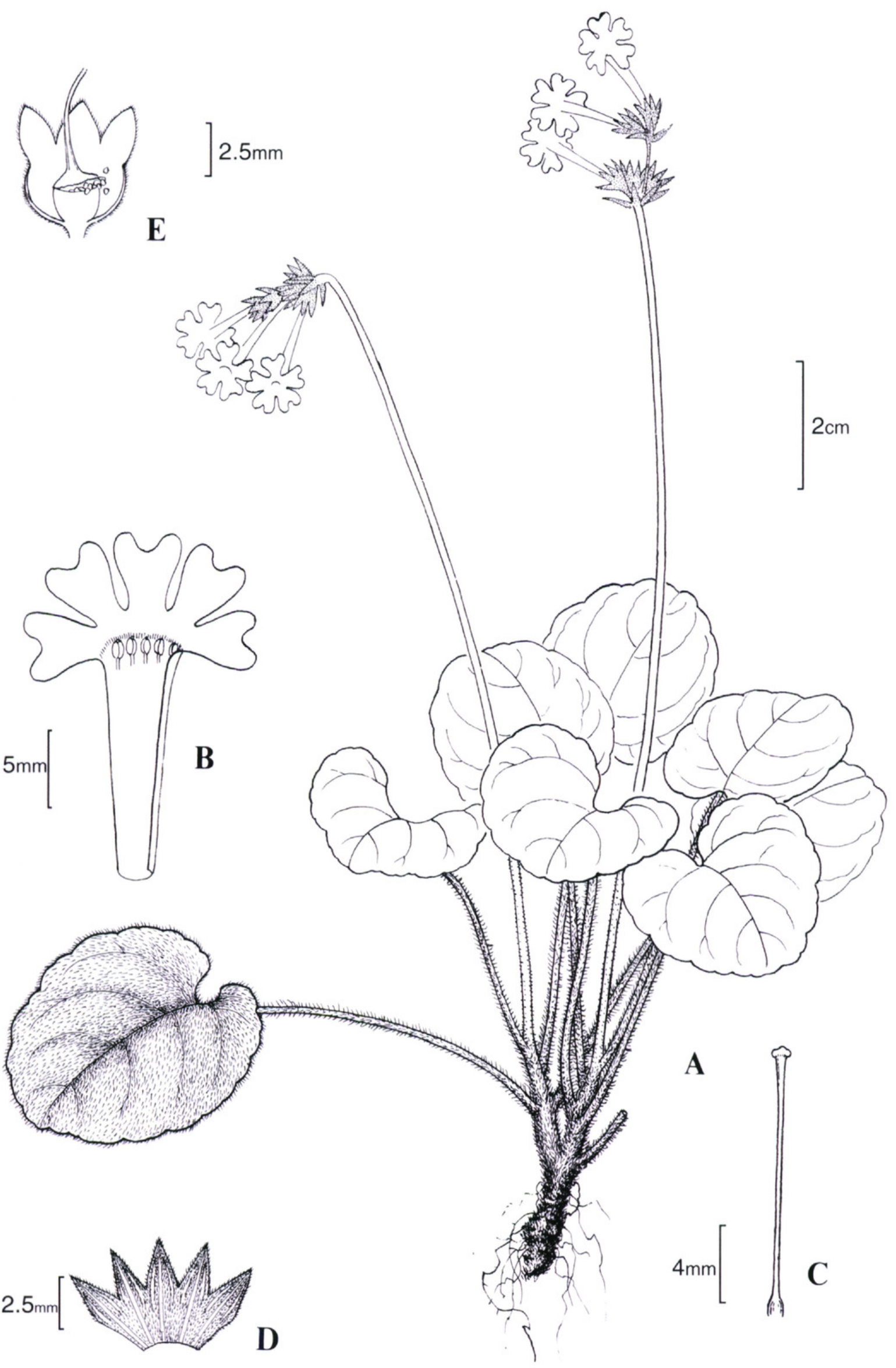

Figure 1. Primula calyptrata X. Gong \& R. C. Fang. - A. Habit. - B. Opened corolla, internal view showing the position of the stamens and hairs. - C. Pistil. - D. Opened calyx, external view-E. Capsule, showing dehiscent manner. Drawn by Yang Jian-kun from the holotype, X. Gong 02815 (KUN). 
tube $1.7 \mathrm{~cm}$ long with a hairy annulus inside, limb 1.5-1.8 cm diam., lobes oblong-obovate, deeply emarginate; homostylous, stamens inserted in throat, anthers below annulus; style ca. $1.7 \mathrm{~cm}$, subequal to corolla tube. Capsule enclosed in calyx tube, dehiscing by means of a calyptra.

Distribution. Known only from the type and paratype specimens collected from both Xiajinchang and Zhongzai forests of Malipo County of southeastern Yunnan, China.

Habitat and phenology. Understory species in an evergreen broad-leaf forest composed of members of the Magnoliaceae, Fagaceae, and Lauraceae, growing on limestone with moss; alt. 17001870 m; flowering March-April, fruiting in August.

Primula calyptrata is distinguished from the other species of Primula sect. Carolinella by having short stems and a leaf blade that is purple on the abaxial surface. This species is closely related to Primula intanoensis T. Yamazaki collected from Thailand, but can be distinguished by stems 2-2.5 $\mathrm{cm}$ long, leaves alternate, corollas purple, tubes 1.7 $\mathrm{cm}$ long, limbs $1.5-1.8 \mathrm{~cm}$ in diameter, and pedicels $2-4 \mathrm{~mm}$ long. Primula intanoensis is stemless, with leaves in a rosette, corollas white, tubes a little longer than to half again as long as the calyxes, limbs $0.8 \mathrm{~cm}$ in diameter, and pedicels $5-7 \mathrm{~mm}$ long.

Paratype. CHINA. SE Yumnan: Malipo County, Zhongzai, 1700 m, 23 Mar. 2002, Yumin Shui et al. 20336 (KUN).

With the inclusion of the species described here, 11 species are known in Primula sect. Carolinella.

\section{Key to the Species of Primula Section Carolinella}

1a. Inflorescences umbellate, umbels 1 or 2 superimposed, 2- to 6(9)-flowered; leaf blade pubescent.

2a. Leaf blade suborbicular or ovate-elliptic, base distinctly cordate, both surfaces markedly pubescent; flowers homostylous. 3a. Stem 2-2.5 cm long, leaves alternate; corolla purple, tube $1.7 \mathrm{~cm}$ long, 2-3 times as long as calyx, limb 1.5-1.8 cm diam.; China ... . . P. calyptrata X. Gong \& R. C. Fang

3b. Stem absent; leaves a rosette; corolla white, tube a little longer than to half as long again as the calyx, limb ca. $0.8 \mathrm{~cm}$ diam.; Thailand ... $\ldots \ldots$. . P. intanoensis T. Yamazaki

2b. Leaf blade oblong, elliptic, broadly ovate or broadly elliptic, base broadly cuneate or cordate, both surfaces pubescent or adaxially glabrous; flowers heterostylous.

4a. Pedicel and calyx glabrous; leaves densely pilose on both surfaces; China .........

P. levicalyx C. M. Hu \& Z. R. Xu

4b. Pedicel and calyx fulvous pilose; leaves pubescent on margin and abaxial surface.

5a. Leaf blade subcordate or rounded at base; calyx 4.5-7.5 mm, parted to middle; China . . . . . . .. . P. wangii F. H. Chen \&

5b. Leaf blade cuneate or rounded at base.

6a. Calyx 3-4 mm, parted to $2 / 3$; China ....... .... P. kweichouensis

W. W. Smith

6b. Calyx 6-7 mm, parted to $1 / 3$; China ....... P. kwangtungensis

W. W. Smith

1b. Inflorescences abbreviated or almost umbellate, (6)12- to 28-flowered; leaf blade glabrous or glabrescent; flowers heterostylous.

7a. Leaf blade acute or acuminate at apex.

8a. Leaf blade cuneate or rounded at base; calyx ca. $3 \mathrm{~mm}$, inconspicuously 5-veined; China, Vietnam ... . ........ P. henryi (Hemsley) Pax

8b. Leaf blade cordate at base; calyx $7-$ $10 \mathrm{~mm}$, prominently 10 -veined; China, Vietnam ... P. chapaensis Gagnepain

7b. Leaf blade obtuse or rounded at apex.

9a. Leaf blade cordate at base.

10a. Leaf blade elliptic-ovate to broadly ovate, $4.5-6 \times 3.5-5.5$ $\mathrm{cm}$; petiole $2-5 \mathrm{~cm}$ long; Vietnam ................ . P. cardioeides W. W. Smith \& H. R. Fletcher

10b. Leaf blade oblong to suborbicular or ovate-rounded, $7-18 \times$ 5-15 cm; petiole $7-26 \mathrm{~cm}$ long; China .. P. partschiana Pax

9b. Leaf blade broadly cuneate to subrounded at base; China ....... ...... P. rugosa N. P. Balakrishnan

Acknowledgments. The authors are grateful to Pan Yue-zhi for help with fieldwork and Yang zhiYun for cultivating and observing the plants.

Literature Cited

Chen F-H. \& Hu Q-M. 1990. Primulaceae. In: Flora Reipublicae Popularis Sinicae 59(2): 59-66. Science Press, Beijing.

Hu Q-M. 1994. On the geographical distribution of the Primulaceae. J. Trop. Subtrop. Bot. 2(4): 1-14.

Kong H-Z. \& Liu J-Q. 1999. Karyomorphology of the genus Pomatosace Maxin. (Primulaceae). Act. Phytotax. Sin. 37(5): 445-450.

Pax, F. \& R. Knuth. 1905. Primulaceae. In: A. Engler, Das Pflanzenreich. Vol. 27: 1-15. Verlag von Wilhelm Engelmann, Leipzig. 


\section{$2 \mathrm{BHL}$ Biodiversity Heritage Library}

Xun, Gong and Fang, Rhuicheng. 2003. "Primula calyptrata, a New Species in Section Carolinella (Primulaceae) from Yunnan, China." Novon a journal of botanical nomenclature from the Missouri Botanical Garden 13, 193-195. https://doi.org/10.2307/3393517.

View This Item Online: https://www.biodiversitylibrary.org/item/14673

DOI: https://doi.org/10.2307/3393517

Permalink: https://www.biodiversitylibrary.org/partpdf/122142

\section{Holding Institution}

Missouri Botanical Garden, Peter H. Raven Library

\section{Sponsored by}

Missouri Botanical Garden

\section{Copyright \& Reuse}

Copyright Status: In copyright. Digitized with the permission of the rights holder.

License: http://creativecommons.org/licenses/by-nc-sa/3.0/

Rights: https://biodiversitylibrary.org/permissions

This document was created from content at the Biodiversity Heritage Library, the world's largest open access digital library for biodiversity literature and archives. Visit BHL at https://www.biodiversitylibrary.org. 